\title{
Health Risks from Indoor Formaldehyde Exposures in Northwest Weatherized Residences
}
P. J. Mellinger
L. E. Sever

October 1986

Prepared for

the Bonneville Power Administration under a Related Services Agreement with the U.S. Department of Energy under Contract DE-AC06-76RLO 1830

Pacific Northwest Laboratory

Operated for the U.S. Department of Energy by Battelle Memorial Institute 


\title{
DISCLAIMER
}

This report was prepared as an account of work sponsored by an agency of the United States Government. Neither the United States Government nor any agency thereof, nor Battelle Memorial Institute, nor any of their employees, makes any warranty, expressed or implied, or assumes any legal liability or responsibility for the accuracy, completeness, or usefulness of any information, apparatus, product, or process disclosed, or represents that its use would not infringe privately owned rights. Reference herein to any specific commercial product, process, or service by trade name, trademark, manufacturer, or otherwise, does not necessarily constitute or imply its endorsement, recommendation, or favoring by the United States Government of any agency thereof, or Battelle Memorial Institute. The views and opinions of authors expressed herein do not necessarly state or reflect those of the United States Government or any agency thereof, or Battelle Memorial Institute.

\author{
PACIFIC NORTHWEST LABORATORY \\ operated by \\ BATTELLE \\ for the \\ UNITED STATES DEPARTMENT OF ENERGY \\ under Contract DE-AC06-76RLO 1830
}

\begin{tabular}{|c|c|}
\hline \multirow{2}{*}{\multicolumn{2}{|c|}{ Printed in the United States of Americal }} \\
\hline & \\
\hline \multicolumn{2}{|c|}{$\begin{array}{l}\text { Available from } \\
\text { National Technical Information Service }\end{array}$} \\
\hline \multicolumn{2}{|c|}{ United States Department of Commerce } \\
\hline \multicolumn{2}{|c|}{$\begin{array}{c}5285 \text { Port Royal Road } \\
\text { Springfield, Virginia } 22161\end{array}$} \\
\hline \multirow{2}{*}{\multicolumn{2}{|c|}{$\begin{array}{l}\text { NTIS Price Codes } \\
\text { Microfiche A01 }\end{array}$}} \\
\hline & \\
\hline \multicolumn{2}{|c|}{ Printed Copy } \\
\hline & Price \\
\hline Pages & \\
\hline 001-025 & $\mathrm{A} 02$ \\
\hline 026-050 & $\mathrm{A} 03$ \\
\hline 051-075 & A04 \\
\hline 076-100 & A05 \\
\hline $101-125$ & A06 \\
\hline $126-150$ & A07 \\
\hline $151-175$ & $\mathrm{~A} 0 \mathrm{~B}$ \\
\hline $176-200$ & $A 09$ \\
\hline 201-225 & A010 \\
\hline 226-250 & A011 \\
\hline 251-275 & A012 \\
\hline $276-300$ & A013 \\
\hline
\end{tabular}


PNL -6058

UC-41

HEALTH RISKS FROM INDOOR FORMALDEHYDE

EXPOSURES IN NORTHWEST WEATHERIZED RESIDENCES

P. J. Mellinger

L. E. Sever (a)

October 1986

Prepared for

the Bonneville Power Administration under a Related Services Agreement with the U.S. Department of Energy Contract DE-AC06-76RLO 1830

Pacific Northwest Laboratory

Richland, Washington 99352

(a) Division of Birth Defects and Development Disabilities

Center for Environmental Health

Center for Disease Control

Public Health Service

U.S. Department of Health and Human Services

Atlanta, Georgia 


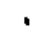

. 


\section{$\underline{\text { SUMMARY }}$}

The level of formaldehyde that may occur in households participating in the Bonneville Power Administration (BPA) energy conservation program was estimated in the BPA Weatherization Environmental Impact Statement (EIS). The number of Pacific Northwest residents that live in four different electrically heated residential types were calculated. BPA estimates that a maximum of 85\% of the residents will participate in the BPA program. Therefore, the estimated indoor formaldehyde concentrations are multiplied by the population estimated to be exposed to arrive at an estimated population exposure.

Conflicting opinions on the potential hazards associated with formaldehyde exposure triggered a national workshop to address the toxicological questions concerning the health effects of formaldehyde. Because of the limited nature of the available toxicological data, carcinogenic risk assessment is an uncertain, controversial process. Since quantitative human data are not available to derive a dose-response curve for formaldehyde risk assessment, nonhuman data are used. In the case of formaldehyde, data from animals exposed to high concentrations are used to estimate human risk at much lower concentrations. Ultimate estimates of risk may vary by orders of magnitude, depending on the assumptions made regarding exposure concentrations, high-dose to low-dose extrapolations, and extrapolations of animal data to human risk.

One objective of this study was to present the several steps that make up a risk assessment and to examine any additional (more recent) data that might alter significantly the risk estimates presented in the 1984 EIS. Rat inhalation chronic bioassay data from a study sponsored by the Chemical Industry Institute of Toxicology (CIIT) have been used to develop a risk equation that was subsequently used by BPA in its EIS. The CIIT data base remains the only acceptable animal data that can support the estimation of a dose-response curve. The development of mathematical models continues with a great deal of energy, and the use of different models is largely responsible for the great variability of the formaldehyde risk estimates. While one can calculate different values for carcinogenic risk associated with formaldehyde exposure than were presented earlier in the BPA EIS, they are not likely to be any better. 


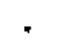

$\times$ 


\section{ACKNOWLEDGMENTS}

We thank W. F. Sandusky for the opportunity of contributing to his Indoor Air Pollution project. We also are indebted to D. D. Mahlum and the Center for Disease Control, Atlanta, Georgia, for their constructive criticism and to C. F. Schauls and V. K. Hopkins for typing the manuscript. 


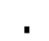

. 
CONTENTS

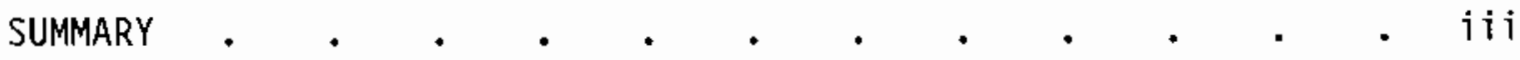

ACKNOWLEDGMENTS $\quad . \quad$. . . . . . . . . . .

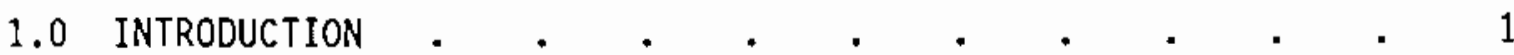

2.0 EXPOSURE TO FORMALDEHYDE $. \quad . \quad$. . . . . . . 3

2.1 ENVIRONMENTAL "BACKGROUND" SOURCES AND EXPOSURE .

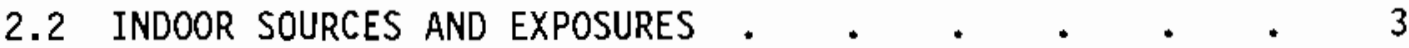

2.3 EXPOSED POPULATIONS $\quad$ • . . . . . . . 5

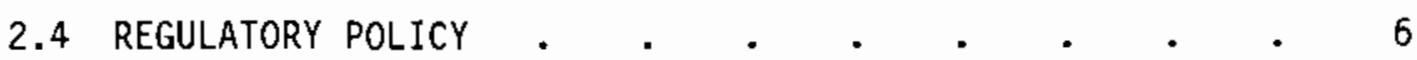

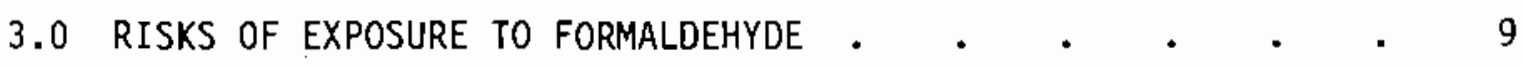

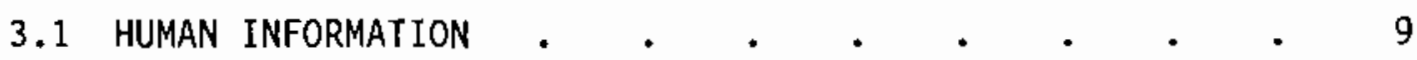

3.1 .1 Human Experience . . . . . . . . . 9

3.1 .2 Epidemiological Data . . . . . . . 9

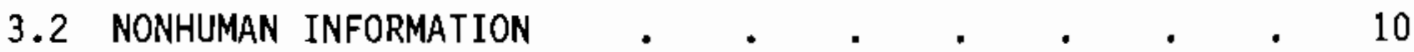

3.3 APPARENT FACTS . . . . . . . . . . 11

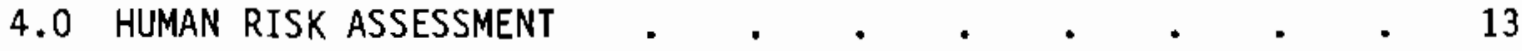

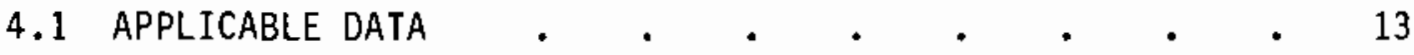

4.2 DOSE RESPONSE MODELS . . . . . . . . . . . . 13

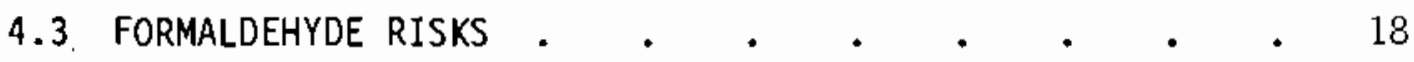

4.4 RISKS IN PERSPECTIVE $\quad . \quad$. $\quad . \quad . \quad . \quad$. 19

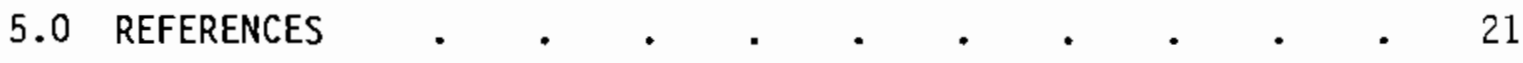




\section{$\underline{\text { TABLES }}$}

2.1 Average Air Concentrations of Formaldehyde that May

Result from BPA Weatherization Programs -- Worst Case . . 5

2.2 Laws, Guidelines, and Proposed Standards for Formaldehyde

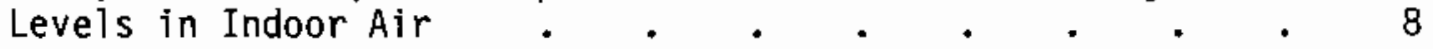

4.1 Lifetime Estimates of Excess Carcinogenic Risk from Exposure to Formaldehyde . . $\quad . \quad$.

4.2 Potential Cancer Risk from a Lifetime Exposure to

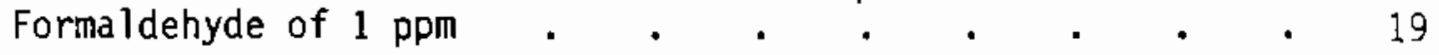

4.3 Voluntary Activities that Carry a Risk of One Death for Each 100,000 People Participating . . . . . . 20 


\subsection{INTRODUCTION}

The quality of indoor residential air is determined mostly by the occupants' activities, including the use of appliances, chemicals, and tobacco. other sources affecting indoor air quality are construction materials of the residence and the household furnishings. In addition, outside air can penetrate to the indoors, affecting indoor air quality. All of these sources can contribute pollutants. The Bonneville Power Administration (BPA) has begun an energy conservation program to provide residence tightening and other measures to reduce energy consumption in certain types of residences. Some of these measures would restrict the flow of outside air into the residence and thereby create the possibility of increasing the indoor air concentrations of a variety of pollutants. One such pollutant, formaldehyde, is the subject of this report.

Formaldehyde is a colorless, flammable gas with a strong, pungent odor. It can form explosive mixtures with air and oxygen. As an important industrial chemical of major commercial use, formaldehyde is found throughout the indoor and outdoor environment. Formaldehyde is usually manufactured by reacting methanol vapor and air over a catalyst; this results in formaldehyde containing trace amounts of methanol and formic acjd. Over the last 30 years, the annual production and domestic use of formaldehyde in the United States has increased sixfold from 1 billion lbs. to about 6 billion lbs. (EPA 1984).

Half of the formaldehyde produced is used to make synthetic resins such as urea- and phenol-formaldehyde resins, which are used primarily as adhesives when making particleboard, fiberboard, and plywood. Urea-formaldehyde concentrates are also used in various coating processes, in paper products, and in making foams for thermal insulation. The textile industry uses formaldehyde for producing creaseproof, crushproof, flame resistant, and shrinkproof fabrics. Acetal resins, made from formaldehyde, are used to mold plastic parts for automobiles, home appliances, hardware, and garden and sporting equipment. Formaldehyde is used in some medicines because it modifies and reduces the toxicity of viruses, venoms, and irritating pollens. The use of formaldehyde in embalming fluids is now required in the United States. 
In indoor air, formaldehyde can originate from many sources, such as particleboard, fiberboard, plywood, and urea-formaldehyde foam insulation (UFFI). The purpose of this risk assessment is to quantify the source, release scenario, and population exposure (Chapter 2.0); to explore the availability of human and nonhuman data to support a risk assessment (Chapter 3.0); and to estimate the potential health effects from the inhalation of formaldehyde.

Several independent risk assessments have been conducted recently, and conflicting opinions exist on the hazards associated with formaldehyde exposure. Because of the mounting controversy, the white House Office on Science and Technology Policy requested that the U.S. Environmental Protection Agency (EPA) work with the National Center for Toxicological Research to conduct a Consensus workshop on Formaldehyde. This workshop brought together scientists from academia, government, industry, and public interest groups to address the toxicological questions concerning the health effects of formaldehyde. Their consensus, published in 1984, is reviewed here; additional individual references have also been reviewed and cited. 


\subsection{EXPOSURE TO FORMALDEHYDE}

\subsection{ENVIRONMENTAL "BACKGROUND" SOURCES AND EXPOSURE}

Environmental levels of formaldehyde reported in ambient air have generally been below 10 to 15 parts per billion (ppb), except for situations of heavy traffic and/or photochemical smog, when concentrations of 90 to $150 \mathrm{ppb}$ have been reported. These urban concentrations appear to have decreased since the 1960s and are likely to decrease further as automobile emissions are progressively reduced. Typical annual average formaldehyde concentrations in outside air in the Pacific Northwest are estimated to be about 4 ppb (BPA 1984, p. 3.11).

\subsection{INDOOR SOURCES AND EXPOSURE}

In conventional homes older than about 5 years, the mean concentrations of formaldehyde are usually below 0.05 parts per million (ppm). Only a fraction of them exceed $0.1 \mathrm{ppm}$, which is the American Society of Heating, Refrigeration, and Air-Conditioning Engineers (ASHRAE) ceiling guideline for comfort, and the standard established in several foreign countries. In some residences (mobile homes, homes with UFFI, new houses, energy-efficient and perhaps weatherized homes), mean levels of formaldehyde are significantly higher, sometimes exceeding $0.1 \mathrm{ppm}$. Mean levels appear to be highest in mobile homes. Measurements of indoor formaldehyde concentrations in mobile homes, following complaints by the residents, were $0.9 \mathrm{ppm}$ in Wisconsin, $0.4 \mathrm{ppm}$ in Minnesota, and $0.38 \mathrm{pPm}$ in washington (BPA 1984). Although mean formaldehyde levels in different classes of residences are reasonably well established, temporal patterns of fluctuation are poorly characterized.

One major factor in indoor formaldehyde concentration is the extent of use and type of insulation and building materials. Levels of formaldehyde are highest in new residences and decline steadily as the emission rates of these materials decline. The half-life is 4 to 5 years for mobile homes and new homes where pressed-wood products are the primary source of formaldehyde. For UFFI homes, the half-life is less than 1 year.

A second major factor in indoor formaldehyde concentrations is the rate of exchange of indoor air with outside air. Single-family attached residences 
and apartments tend to have lower air-exchange rates than those for singlefamily detached residences. Mobile homes have the lowest average air-exchange rate (BPA 1984). Therefore, by implementing an energy conservation program to provide residential tightening, natural air-exchange rates would be decreased further, resulting in a potential increased concentration of indoor pollutants.

The major sources of indoor concentrations of formaldehyde are articles fabricated with urea-formaldehyde-based glues and resins that are used in large amounts in the construction and furnishing of the home. Examples include UFFI, hardwood plywood paneling, and particleboard underlays or decking. Medium-density fiberboard is a sufficiently strong emitter that even smaller articles such as furniture can elevate indoor levels of formaldehyde significantly. Transient increases in formaldehyde levels can also be caused by burning cigarettes [cigarette smoke contains as high as 40 ppm by volume, (Hileman 1984)], gas-fired appliances, and wood-burning stoves. In extreme cases (heavy smoking or poorly tuned heaters), these transient increases of formaldehyde in the indoor air can exceed $0.1 \mathrm{ppm}$. Another source of indoor formaldehyde is from outside air, although this is usualiy an insignificant contribution.

Formaldehyde appears in a variety of consumer products, such as cosmetics, shampoos, drugs, and disinfectants. In 1981 the Food and Drug Administration listed 805 products containing formaldehyde. However, the extent of exposure to these products via skin contact or inhalation has not been quantified.

In the past, BPA has implemented a partial residential weatherization program [the No-Action Alternative as evaluated in its weatherization EIS (BPA 1984)] that may result in elevated formaldehyde air concentrations. The estimated increased air concentrations that may be expected are presented in Table 2.1, Column 2. The implementation of the expansion of the present BPA program (expanded program) is estimated to further reduce air-exchange rates from 5 to $30 \%$ depending upon the tightening measures selected by the participants (BPA 1984, Table 4.6). If any of the tightening measures are used, it is expected that the formaldehyde concentrations given in column 2 of Table 2.1 would increase because of the reduced air exchange. The potential formaldehyde air concentrations that may occur following expanded residential 
TABLE 2.1. Average Air Concentrations of Formaldehyde (ppm) that May Result from BPA Weatherization Programs -- Worst Case

\begin{tabular}{|c|c|c|c|c|}
\hline \multirow[t]{2}{*}{ Residence Type } & \multicolumn{2}{|c|}{ Partial Program $^{(a)}$} & \multicolumn{2}{|c|}{ Expanded Program ${ }^{(b)}$} \\
\hline & $\begin{array}{c}\text { Reasonable } \\
\text { Worst-Case } \\
\text { Value } \\
\end{array}$ & Range & $\begin{array}{c}\text { Reasonable } \\
\text { Worst-Case } \\
\text { Value } \\
\end{array}$ & Range \\
\hline $\begin{array}{l}\text { Single-family } \\
\text { detached }\end{array}$ & 0.2 & 0.03 to 0.8 & 0.3 & 0.03 to 0.9 \\
\hline $\begin{array}{l}\text { Single-family } \\
\text { attached }\end{array}$ & 0.5 & 0.05 to 1.4 & 0.8 & 0.06 to 1.65 \\
\hline Apartment & 0.7 & 0.08 to 2.1 & 1.1 & 0.09 to 2.5 \\
\hline Mobile homes & 0.8 & 0.01 to 5.1 & 1.1 & 0.01 to 6.1 \\
\hline
\end{tabular}

(a) BPA 1984, Table 4.2.

(b) BPA 1984, Table 4.7.

tightening are shown in column 3 of Table 2.1. These air concentrations are used in the health effects assessment (Section 4.3).

A11 reasonable worst-case values of formaldehyde that may result from the expanded BPA weatherization program exceed ASHRAE guidelines of 0.1 ppm (BPA 1984, Appendix N); both apartments and mobile homes exceed the National Institute of Occupational Safety and Health (NIOSH) ceiling recommendation of $1 \mathrm{ppm}$ (workplace), but none of the estimated formaldehyde air concentrations exceed applicable Occupational Safety and Health Administration (OSHA) regulations (see Section 2.4 ).

\subsection{EXPOSED POPULATIONS}

In 1981, about $2.2 \times 10^{6}$ (2.2 million) people in the United States lived in mobile homes that were less than 5 years old, and about 1.3 to $1.6 \times 10^{6}$ people were living in homes insulated with UFFI during the preceding 5 years (EPA 1984). The Consumer Product Safety Commission (CPSC) estimated that $1.75 \times 10^{6}$ people were living in homes insulated with UFFI during the preceding 
9 years. In the Consensus Workshop report, the remainder of the U.S. poputation $\left(220 \times 10^{6}\right)$ is assumed to be exposed to formaldehyde at Tevels characteristic of conventional homes (0.05 ppm in older homes seldom exceeding $0.1 \mathrm{ppm})$.

In the Northwest, it is assumed that about $85 \%$ of the electrically heated households would respond favorably to residence tightening measures. Therefore, the potential population that may be exposed to elevated formaldehyde concentrations can be broken down by residence type. About $1.8 \times 10^{6}$ people would be living in single-family detached residences, about $4.9 \times 10^{5}$ people in single-family attached housing, about $5.4 \times 10^{5}$ people in apartments, and about $4.9 \times 10^{5}$ people in mobile homes. The estimated "background" formaldehyde concentrations that these people may be exposed to with no weatherization is presented in Section 2.1. The potential formaldehyde concentrations that may result from partial and expanded weatherization efforts are presented in Table 2.1.

The EPA included new mobile-home and conventional-home residents (non-UFFI), and apparel workers as the populations estimated to have by far the greatest lifetime numbers of excess tumors, and concluded that these populations ". . should receive priority attention as significant risk of widespread harm." (EPA 1984, P. 65).

\subsection{REGULATORY POLICY}

No federal standard exists for regulating formaldehyde levels in residences; however, several states have established or contemplate setting indoor standards similar to those in European countries (BPA 1984).

On May 18, 1984, the EPA listed formaldehyde as a priority chemical for regulatory assessment under section $4(f)$ of the Toxic Substances Control Act (TSCA), reversing an earlier decision of the agency in February 1982. Under section 4(f), EPA will give priority consideration to human formaldehyde exposure in two areas because of the large number of people involved: clothing workers who handle textiles treated with formaldehyde-based resins and residents of conventional and mobile homes that contain construction materials with similar resins. According to this section of the act, the EPA administrator must act if ". . . there may be a reasonable basis to conclude that a chenical 
presents or will present a significant risk of serious or widespread harm to human beings from cancer, gene mutations, or birth defects. . " (Hileman 1984).

On the same day formaldehyde was 1 isted under section $4(f)$, EPA issued an advance notice of proposed rulemaking to initiate a full regulatory investigation concerning formaldehyde exposure of textile workers and people who live in conventional and mobile housing. In the decision to regulate, the economic costs will be weighed against the benefits provided by the substance. The EPA was reported to be considering recommendations to set a $0.1 \mathrm{ppm}$ formaldehyde products standard (Inside EPA 1985).

The Office of Housing and Urban Development (HUD) recently proposed changes in its manufactured-housing regulations that would limit indoor ambient levels of formaldehyde to $0.4 \mathrm{ppm}$ (Hileman 1984; EPA 1984). The limit would be achieved by setting product emission standards for particleboard ( $0.3 \mathrm{ppm})$ and plywood (0.2 ppm) as published in the Federal Register of August 16, 1983 (48 FR 37136) (EPA 1984).

A variety of published laws, guidelines, and proposed standards for formaldehyde concentrations in indoor air are presented in Table 2.2. 
TABLE 2.2. Laws, Guidelines, and Proposed Standards for

Formaldehyde Levels in Indoor Air (BPA 1984)

\begin{tabular}{|c|c|c|}
\hline Regulatory Body & $\begin{array}{c}\text { Formaldehyde Exposure } \\
\text { Standard } \\
\end{array}$ & Type of Standard \\
\hline $\begin{array}{l}\text { Occupational Safety \& Health } \\
\text { Administration (OSHA) } \\
\text { (10 ppm, 30-min average) }\end{array}$ & $\begin{array}{l}3 \text { ppm average } \\
5 \text { ppm ceiling } \\
1 \text { ppm (carcinogen) } \\
1.5 \mathrm{ppm} \text { (irritant) }\end{array}$ & $\begin{array}{l}\text { Regulation } \\
\text { (workplace) } \\
\text { Proposed (b) } \\
\text { Proposed (b) }\end{array}$ \\
\hline $\begin{array}{l}\text { National Institute of Occu- } \\
\text { pational Safety and Health } \\
\text { (NIOSH) }\end{array}$ & 1 ppm ceiling & $\begin{array}{l}\text { Recommended } \\
\text { (workplace) }\end{array}$ \\
\hline $\begin{array}{l}\text { Office of U.S. Housing and } \\
\text { Urban Development (HUD) }\end{array}$ & $0.4 \mathrm{ppm}$ & $\begin{array}{l}\text { Regulation (manu- } \\
\text { factured housing }\end{array}$ \\
\hline $\begin{array}{l}\text { American Society of Heating, } \\
\text { Refrigeration, and Air Con- } \\
\text { ditioning Engineers (ASHRAE) }\end{array}$ & 0.1 ppm ceiling $(\mathrm{c})$ & $\begin{array}{l}\text { Recommended (air } \\
\text { for ventilation) }\end{array}$ \\
\hline State of Wisconsin & $0.4 \mathrm{ppm}$ ceiling & $\begin{array}{l}\text { Pending (ambient } \\
\text { air quality } \\
\text { standard) }\end{array}$ \\
\hline State of Minnesota & 0.4 pprn ceiling & $\begin{array}{l}\text { Product standard } \\
\text { HUD Target }\end{array}$ \\
\hline Canada & $0.1 \mathrm{ppm}$ ceiling & Guidelines \\
\hline $\begin{array}{l}\text { The Netherlands, Sweden, } \\
\text { Denmark, Federal Republic of } \\
\text { Germany }\end{array}$ & $0.1 \mathrm{pp}$ n ceiling & $\begin{array}{l}\text { Regulation (non- } \\
\text { occupational) }\end{array}$ \\
\hline \multicolumn{3}{|c|}{$\begin{array}{l}\text { (a) 8-h time weighted average (TWA). } \\
\text { (b) Two exposure limits for formaldehyde have been proposed by OSHA, one based } \\
\text { on its potential carcinogenicity and the other based on its irritating } \\
\text { qualities (C\&EN 1985). } \\
\text { (c) Continuous exposure. }\end{array}$} \\
\hline
\end{tabular}




\subsection{RISKS OF EXPOSURE TO FORMALDEHYDE}

The Consensus Workshop considered scientific papers published, in press, and in manuscript. Its discussion, as well as this one, is limited to studies in which the material can be related to a definable population.

\subsection{HUMAN INFORMATION}

Much human data have been gathered concerning formaldehyde and its potential health impacts. However, in almost every case the data are too incomplete to support a strong statement about the risks of formaldehyde exposure in man. Unfortunately, this is characteristic of human risk assessments.

\subsubsection{Human Experience}

Precise thresholds have not been established for the irritant effects of inhaled formaldehyde. However, within the range of 0.1 to $3 \mathrm{ppm}$, most people experience irritation of the eyes, nose, and throat. Between 10 and $20 \mathrm{ppm}$, symptoms are severe, and breathing becomes difficult. Lower airways and pulmonary effects are likely to occur between 5 and $30 \mathrm{ppm}$ (EPA/NCTR 1984). Exposures between 50 and $100 \mathrm{ppm}$ cause serious injury to the respiratory tract, such as pulmonary edema, inflammation, pneumonitis, and pneumonia.

Formaldehyde is a primary skin-sensitizing agent inducing allergic contact dermatitis. Threshold levels have been reported for cutaneous irritation, and allergic contact dermatitis in man for a single application of $1 \%$ formalin in water will produce an irritant response in approximately $5 \%$ of the population (EPA/NCTR 1984).

\subsubsection{Epidemiological Data}

In the report from the Consensus Workshop, epidemiological data were gathered and organized by organ of interest. Eleven different organs (i.e., brain, lung, and skin) were evaluated for significant excess cancers in many different exposed groups. Of these, increased risks of brain cancer and leukemia are noted among each of three professional groups (embalmers, anatomists, and pathologists) who preserve human tissues with solutions containing formaldehyde and other chemicals. Two conclusions were reached by the workshop participants: 1) the data are sparse and conflicting and do not yet provide 
persuasive evidence of a causal relation between exposure to formaldehyde and cancer in man, and 2) it is not possible to exclude the possibility that formaidehyde is a human carcinogen, in view of the small number of person-years of follow-up in subjects followed for 20 years or more and various methodological limitations of the studies.

Recently published epidemiological studies have broadened our knowledge regarding potential carcinogenicity of formaldehyde. These studies have provided stronger evidence in support of conclusions made from previous studies. Significant excesses in cancer risk among textile workers, garment workers, film processors, and chemical workers, to name a few, have been reported (Scott and Margosches 1985).

\subsection{NONHUMAN INFORMATION}

Data on the carcinogenicity of formaldehyde vapor are available for the rat, mouse, and hamster. Formaldehyde gas is carcinogenic for rats and probably for mice, producing nasal tumors following chronic inhalation (exposures in the range of 10 to $30 \mathrm{ppm}$ ). It should be emphasized that the data available for species comparisons are limited to very few experiments.

The first evidence that formaldehyde is a rodent carcinogen was obtained in a chronic inhalation study sponsored by the Chemical Industry Institute of Toxicology (CIIT) (CIIT 1981a). Nearly half of the rats exposed to $14.3 \mathrm{ppm}$ formaldehyde exhibited squamous cell carcinomas of the nasal cavity, whereas only two mice exposed to the same concentration developed tumors. A possible explanation for the apparent difference in rat and mouse response was proposed by Starr, Gibson and Swenberg (1985). A significant difference in the intensity of the respiratory depression reflex in rats and mice exposed to the same ambient air concentration results in the mice receiving a smaller delivered dose. This difference could easily account for the observed reduced carcinogenicity of formaldehyde in the CIIT mouse study. Therefore, the two mouse tumors may have developed from a delivered dose of about half the intended exposure concentration (or about $6 \mathrm{ppm}$ ). This hypothesis is supported by subsequent studies that demonstrated two squamous carcinomas in rats following exposure levels of 6 ppm (CIIT 1981b as referenced in BPA 1984; EPA 1984). 
In 1982, Albert et al. reported induction of squamous cell carcinomas in the nasal cavities of Sprague-Dawley rats following exposure to $14 \mathrm{ppm}$ formaldehyde.

In addition to its carcinogenicity, data reviewed by the Consensus Workshop participants are consistent with formaldehyde acting as a weak mutagen.

There is no convincing experimental evidence that formaldehyde has primary toxic effects at body sites distant from the site of exposure.

\subsection{APPARENT FACTS}

The participants of the Consensus Workshop on Formaldehyde reviewed hundreds of published and unpublished materials. Many data were rejected from further consideration for numerous reasons. While many data did not show clear evidence of biological effects, many other data did. Listed below are several examples of data that reveal effects (EPA/NCTR 1984).

1. Formaldehyde gas is carcinogenic for rats and probably for mice, producing nasal tumors following inhalation exposure. Limited experiments in Syrian hamsters have not demonstrated carcinogenicity. In rats, the carcinogenic response appears nonlinear, being disproportionately higher at the higher concentrations (14 ppm) (p. 343).

2. A substantial excess of human deaths from cancer of the brain is noted among three groups of professional workers (embalmers, anatomists, and pathologists) (p. 338).

3. Formaldehyde is genotoxic in a number of assays and is weakly mutagenic in human cells in culture as well as in other mammalian cells, Drosophila, fungi, and bacteria (p. 343).

4. There are numerous reports that formaldehyde vapor exposure causes direct irritation of both the skin and respiratory tract (p. 344). Within the range of 0.1 to $3 \mathrm{ppm}$, most people experience irritation of the eyes, nose, and throat. Between 10 and $20 \mathrm{ppm}$, sympţoms are severe, and breathing becomes difficult (p. 345).

5. Experiments in animals show that cellutar damage and inflanmation is induced with increasing severity at concentrations of formaldehyde of 1 to $15 \mathrm{ppm}$ (p. 345). 
With the risk assessment framework and the apparent facts listed above, the Risk Estimation Panel of the Consensus Workshop tried to determine how the available data can be integrated to make reasonable risk estimates (neoplastic and non-neoplastic) for humans exposed to formaldehyde at various levels and through different routes of administration.

Answers were provided for the above question in each major category of effect that was investigated in the Workshop. The responses are remarkably conservative for the presumed intent of the Workshop. The Risk Estimation Panel was unwilling to offer potential quantification for any effect. However, this Panel did find that data from the CIIT rat inhalation chronic bioassay are suitable for modeling the human dose-response relationship ( $p$. 355). 


\subsection{HUMAN RISK ASSESSMENT}

There are no conclusive human data on carcinogenesis resulting from exposure to formaldehyde, which is typical for most risk assessments. This does not eliminate the need to attempt to quantify the potential risks to humans.

The process of quantitative risk assessment (as described by crump and Howe 1985) involves several steps, each potentially involving CONSIDERABLE UNCERTAINTY: 1) extrapolation of risks from high to low dose, 2) extrapolation of risks from animal exposures to human populations, 3) extrapolation of results from one route of exposure to another, 4) extrapolation of results from one temporal exposure pattern to another, and 5) estimation of human exposure levels.

\subsection{APPLICABLE DATA}

When human data are unavailable or inconclusive, animal data must be used as a surrogate. The CIIT rat inhalation chronic bioassay data were endorsed by the Formaldehyde Consensus Workshop as suitable for modeling the human dose-response relationship (EPA/NCTR 1984). The Risk Estimation Panel of the workshop stated, "There are no indications that the response by humans would be different than that exhibited by rats..."

In the BPA weatherization EIS, the quantification of risk was presented using an equation developed by Cohn (1981). Cohn reported on an upper bound carcinogenic risk estimation method developed for the CPSC and based on the CIIT rat data and assumptions from human exposure data. The CIIT data base still appears to be the data base of choice since the publication of the weatherization EIS.

\subsection{DOSE RESPONSE MODELS}

Human risk is calculated by Cohn as lifetime risk following a 9-year, 
16-h/day exposure out of an average lifetime of 70 years. Cohn's (1981) (a) estimation was based on a linear no-threshold dose response model.

The equation developed is as follows:

Upper Value of Risk $=0.00109 \times$ Exposure [Ave. Concentration (ppm) in Residence]

This equation leads to lifetime risk estimates ranging from $1.09 \times 10^{-4}(0.1 \mathrm{ppm}$ formaldehyde) to $5.5 \times 10^{-3}$ (5 ppm formaldehyde) as shown in Table 4.1.

At the CPSC public meeting on the proposal to ban UFFI held on March 20, 1981, Lamm (1981) made several points regarding Cohn's risk assessment that are pertinent here. First, the risk estimates are based on the $95 \%$ upper confidence limits. This does not indicate what the typical or average expected risk might be. The central tendency of the distribution of the factor needs to be considered in the risk estimate. Second, Lam reported that Gibson of CIIT has presented risk estimates for formaldehyde using five different models. In each case, he found the central tendency of lifetime risk to be $10^{-5}$ from a lifetime exposure of $1 \mathrm{ppm}$. A lifetime risk of $10^{-8}$ was estimated from an exposure of about $0.2 \mathrm{ppm}$ (Table 4.1). However, during the early 1980s, considerable model development occurred, and it is still going on. These models, estimated primarily with tumor incidence data gathered at highadministered exposure levels, are extrapolated downward to predict potential results at low exposures. This high-dose to low-dose extrapolation step has received much attention. This step is generally accomplished by fitting a mathematical dose response model to experimental carcinogenesis data collected at high doses and using the fitted model to estimate low-dose response. A number of dose response models have been proposed for this purpose. These include the probit, logit or logistic, Weibull or extreme value, gamma multihit, and multistage. An excellent review is provided by Krewski and Van Ryzin (1981). It appears that variations of the multistage model are currently receiving the most use.

(a) Meno from M. S. Cohen. 1981. "Revised Carcinogenic Risk Assessment for Urea Formaldehyde Foam Insulation: Estimates of Cancer Risk Due to Inhalation of Formaldehyde Released by UFFI." Consumer Product Safety Commission, Washington, D.C. 
TABLE 4.1. Lifetime Estimates of Excess Carcinogenic Risk from Exposure to Formaldehyde

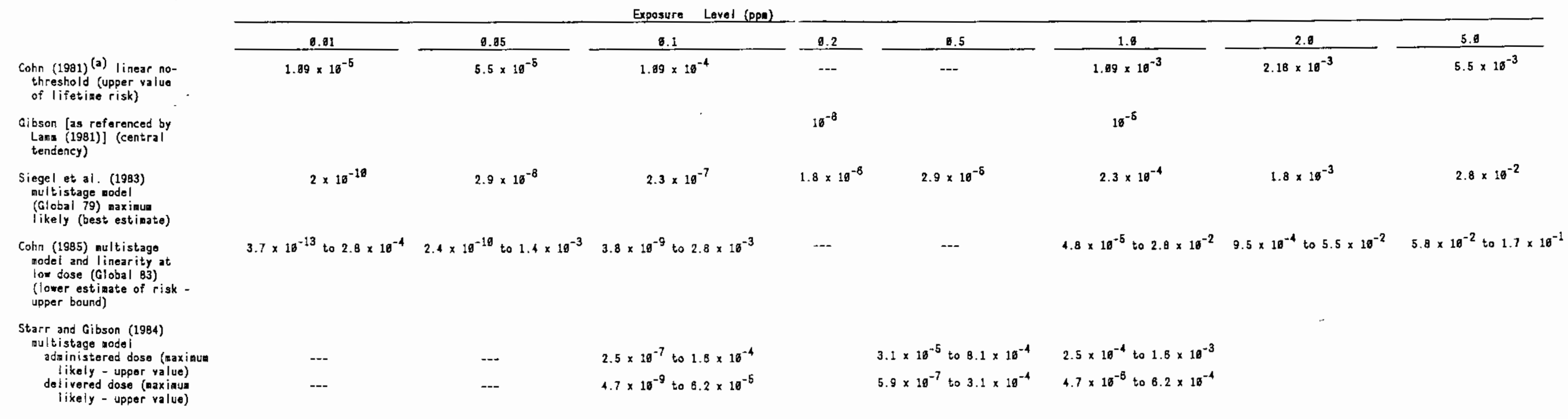

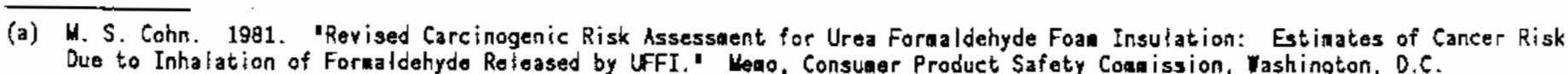



Siege \}, Frankos and Schneiderman (1983) used a multistage model leading to linearity at low doses (Global 79 Computer Program - Crump and Watson 1979 (a) and Crump 1981) to report both maximum likelihood "best" estimates and upper 95th percentile confidence limit estimates of risk from exposure to formaldehyde. From their equation, and the use of the CIIT data base, it was found that the cubic term is the only term needed to express the dose-response relationship. Thus, the response is a function of the cube of the exposure level. Maximum likely ("best" estimate) dose-response values are shown in Table 4.1 for $0.01 \mathrm{ppm}$ up to $5 \mathrm{ppm}$. Because a cubic curve is concave upward, the estimated risk increases rapidly above $1 \mathrm{ppm}$ and decreases (less) rapidly below this value. The curve is essentially linear below an exposure level of about $0.1 \mathrm{ppm}$.

Cohn (1985) refined his previous estimates of formaldehyde risk by applying to the CIIT rat data a factor that would account for the difference of the duration of the experimental exposure to that of a lifetime exposure, and by using a multistage model with a linear slope at low dose (Global 1983; Howe and Crump 1983). Cohn reported lower estimates of lifetime risk and upper-bound estimates of lifetime risk as shown in Table 4.1.

Starr, Gibson and Swenberg (1985) and Swenberg et al. (1985) reported that a significant difference in estimates of risk from formaidehyde exposure can occur if one uses the administered dose as opposed to the delivered dose (see Section 3.2). Results from multistage model analyses of the CIIT bioassay data reported as administered dose versus delivered dose (Starr and Gibson 1984) are presented in Table 4.1. It is clear that risk estimates based on delivered dose are smaller than the corresponding estimates based on administered dose.

No appropriate data bases exist that would allow a true validation of the models. Furthermore, Swenberg et at. (1985) bring to our attention that these models give no explicit consideration to factors such as saturable homeostatic mechanisms including deposition, absorption, detoxification, and DNA repair. It is proposed by Swenberg et al, that quantitative risk assessment models

(a) K. S. Crump and W. W. Watson. 1979. "Global 79: A FORTRAN Program to Extrapolate Dichotomous Animal Carcinogenicity Data to Low Doses" (unpublished, but available from senior author). 
incorporate as much mechanistic data as possibie to increase their accuracy. For example, incorporation of data on formaldehyde covalent binding to DNA as a measure of internal exposure reduces the multistage model's maximum likelihood estimate of nasal cancer risk by a factor of 53 at concentrations of 1 ppm or less.

\subsection{FORMALDEHYDE RISKS}

Several lifetime estimates of risk from exposure to formaldehyde are presented in a comparative format in Table 4.1. All of these risk values were estimated from the same set of CIIT animal data. The variabijity is due to the use of different models (employing different assumptions) and a few subtle modeling variations.

To compare the effects of these various risk factors, an example calculation is presented for Northwest mobite home residents.

- Pacific Northwest mobile-home average formaldehyde concentration as a result of implementing tightening measures $=1.1$ ppm (Table 2.1)

- estimated Pacific Northwest mobile-home residents that would elect to have their residence tightened $=4.9 \times 10^{5}$ people (Section 2.3 ).

$$
\begin{aligned}
\text { Lifetime Risk } & =1.1 \mathrm{ppm}\left(4.9 \times 10^{5}\right) \text { (excess cancer risk factor) } \\
& =5.4 \times 10^{5} \text { person ppm (excess cancer risk factor) }
\end{aligned}
$$

For ease of comparison, we will use the lifetime excess cancer risk factors for $1.0 \mathrm{ppm}$ from Table 4.1 .

The lower lifetime risk estimates from exposure to $1.0 \mathrm{ppm}$ formaldehyde (Table 4.1 ) range from about $10^{-6}$ to $10^{-4}$. The two values representing the midrange are about $10^{-5}$ and $10^{-4}$, and the maximum risk estimates range from about $10^{-4}$ to $10^{-2}$. Therefore, if one uses the lowest of the low estimates of lifetime risk $\left(4.7 \times 10^{-6}\right)$ for formaldehyde exposure, a "best" estimate $\left(2.3 \times 10^{-4}\right)$, and the maximum upper-bound estimate $\left(2.8 \times 10^{-2}\right)$ of cancer incidence, the resulting individual risks of cancer incidence can be estimated as shown in Table 4.2. 
TABLE 4.2. Potential Cancer Risk from a Lifetime Exposure to

Formaldehyde of $1 \mathrm{ppm}$

$\begin{array}{lccc} & \text { Lowest Estimate } & \text { Best Estimate } & \text { Upper Bound } \\ \begin{array}{l}\text { Number of Lifetime Cases } \\ \text { Pacific Northwest } \\ \text { mobile homes }\end{array} & 2.53 & 124 & 1.5 \times 10^{4} \\ \begin{array}{l}\text { Number } / 10^{5} \text { people } \\ \text { Individual Lifetime Risk }\end{array} & 5.2 \times 10^{-6} & 2.5 \times 10^{-4} & 3.1 \times 10^{-2} \\ \text { Individual Annual Risk } & 7.4 \times 10^{-8} & 3.6 \times 10^{-6} & 4.4 \times 10^{-4}\end{array}$

An uncertainty assessment should accompany any risk assessment. Some very comprehensive computer programs are being developed to aid in making these judgments (Henrion and Morgan 1985). It would not be surprising if the uncertainty in any of these values ranged from one to two orders of magnitude.

\subsection{RISK IN PERSPECTIVE}

All societies and individuals recognize exposure to personal risk as a normal part of life. Risk, which is usually described in terms of death, can be the result of voluntary actions such as rock climbing, flying in airplanes, and smoking, or involuntary actions such as having a nuclear or a coal-fired plant built near your home. By making a comparison of risk, a person should be able to make an informed decision regarding which activities he is willing to undertake in comparison with the probability that he will suffer death. one way to compare risks is to consider the events that occur over a lifetime. The activity that will be associated with a new energy-efficient home may be exposure to elevated concentrations of pollutants (i.e., formaldehyde is only one). This activity is compared to other voluntary risks in Table 4.3 . The risks of death for each activity is the same, 1 death $/ 100,000$ persons participating in the activity, or a probability of 0.0001 for any one person.

Notice the dimensions of time are used in various fashions for the activities. For example, the exposure of pollutant concentrations is for life, whereas traveling by air or automobile or the act of smoking have no units 
Table 4.3. Voluntary Activities that Carry a Risk of One Death for Each 100,000 People Participating(a)

\begin{tabular}{lll}
\multicolumn{1}{c}{ Activity } & \multicolumn{1}{c}{ Cause of Death } \\
\hline Breathing $1 \mathrm{ppm}$ formaldehyde for life $(b)$ & Cancer \\
Traveling 7000 miles by air & Accident \\
Crossing the ocean 10 times by air & Cancer from cosmic rays \\
Traveling 600 miles by automobile & Accident \\
Living for 2 years in Denver & Cancer from cosmic rays \\
Living for 2 years in a stone building & Cancer from radioactivity \\
Working for 15 weeks in a typical factory & Accident \\
Working for 30 hours in a coal mine & Accident \\
Smoking from 10 to 30 cigarettes & Cancer, heart-lung disease \\
Rock climbing for 15 minutes & Accident \\
3 hr being a man aged 60 & Mortality from all causes
\end{tabular}

\footnotetext{
(a) Taken from upton 1982 and modified to express a risk of $10^{-5}$.

(b) Addition from this study.
}

of time associated with them. This is because the risk of death from these activities is based on iffetime occurrence of the activity. Another way of placing these risks into perspective is to consider that the average car driver traveling 600 miles in 27 days $(10,000 \mathrm{mtles} / \mathrm{yr})$ experiences the same risk of death as he might by breathing $1 \mathrm{ppm}$ of formaldehyde for 70 years. 


\subsection{REFERENCES}

Albert, R. E., A. R. Sellakumar and S. Laskin. 1982. "Nasal Cancer in the Rat Induced by Gaseous Formaldehyde and Hydrogen Chloride." J. Nat1. Cancer Inst. $68: 597$.

BPA (Bonneville Power Administration). 1984. Final Environmental Impact Statement - The Expanded Residential Weatherization Program. DOE/EIS-095F, Bonneville Power Administration, Portland, Oregon.

C\&EN (Chemical \& Engineering News). 1985. "Benzene, Formaldehyde: Workplace Exposure Limits Proposed," December 9, p. 4.

CIIT (Chemical Industry Institute of Toxicology). 1981a. Final Report on a Chronic Inhalation Toxicology Study in Rats and Mice Exposed to Formaldehyde. Battelle Columbus Laboratories, Columbus, ohio.

CIIT (Chemical Industry Institute of Toxicology). 1981b. Data Released to the International Agency for Research on Cancer (IARC) Working Group, October 19, 1981. Research Triangle Park, North Carolina.

Cohn, M. S. 1985. "Description of a Carcinogenic Risk Assessment Used in a Regulatory Proceeding: Formaldehyde." In Risk Quantitation and Regulatory Policy, ed. D. G. Hoel et al., pp. 269-281, Cold Spring Harbor Laboratory, Cold Spring Harbor, New York.

Crump, K. S. 1981. "An Improved Procedure for Low-Dose Carcinogenic Risk Assessment from Animal Data." J. Environ. Pathol. Toxicol. 5:675-684.

Crump, K. S., and R. 8. Howe. 1985. "A Review of Methods for Calculating Statistical Confidence Limits in Low Dose Extrapolation." In Toxicological Risk Assessment, Volume 1, pp. 1B7-203, CRC Press, Boca Raton, Florida.

EPA/NCTR (Environmental Protection Agency/National Center for Toxicological Research). 1984. "Report on the Consensus Workshop on Formaldehyde." Environmental Health Perspectives 58:323-381.

EPA (Environmental Protection Agency). 1984. Formaldehyde: Determination of Significant Risk. 40 CFR Part 765 (OPTS-62033; FRL 2581-5b). Washington, D.C.

Henrion, M., and M. G. Morgan. 1985. "A Computer Aid for Risk and Other Policy Analysis." Risk Analysis 5(3):195-208.

Hileman, B. 1984. "Formaldehyde: Assessing the Risk." Environmental Science and Technology 18(7):216A-221A.

Howe, R. B., and K. S. Crump. 1983. Global 83. Science Research Systems, Inc., Ruston, Louisiana. 
Inside EPA. 1985. "Moore Sends EPA Formaldehyde Regs Back to Staff as Too Lax." 6(46):1 (November 15).

Krewski, D., and J. Van Ryzin. 1981. "Dose Response Models for Quantal Response Toxicity Data." In Statistics and Related Topics, p. 201, North-Holland, New York.

Lamn, S. H. 1981. "Testimony at Consumer Product Safety Commission Public Hearing on Proposal to Ban Urea-Formaldehyde Foam Insulation." March 20, 1981, Washington, D.C.

Scott, C. S., and E. H. Margosches. 1985. "Cancer Epidemiology Relevant to Formaldehyde." J. Environ. Sciences and Health Part C.3(1):107-144.

Siege1, D. M., Y. H. Frankos and M. A. Schneiderman. 1983. "Formaldehyde Risk Assessment for Occupationally Exposed Workers." Regulatory Toxicology and Pharmacology $3: 355-371$.

Starr, T. B., and J. E. Gibson. 1984. "The Importance of Delivered Dose in Quantitative Risk Estimation: Formaidehyde." Toxicologist 4:30.

Starr, T. 8., J. E. Gibson and J. A. Swenberg. 1985. "An Integrated Approach to the Study of Formaldehyde Carcinogenicity in Rats and Mice." In ToxiCological Risk Assessment, Volume II, pp. 195-209, CRC Press, Boca Raton, Florida.

Swenterg, J. A., H. d'A. Heck, K. T. Morgan and T. 8. Starr. 1985. "A Scientific Approach to Formaldehyde Risk Assessment." In Risk Quantitation and Regulatory Policy, ed. D. G. Hoel et al., pp. 255-267, Cold Spring Harbor Laboratory, Cold Spring Harbor, New York.

Upton, A. C. 1982. "The Biological Effects of Low-Level Ionizing Radiation." Scientific American 246(2):41-49. 


\section{DISTRIBUTION}

No. of

Copies

OFFSITE

DOE Division of Biomedica? and Environmental Research Washington, DC 20545

30 DOE Technical Information Center

R. L. Love Bonneville Power Administration Box 3621-KR

Portland, OR 97208-3621

10 L. E. Sever Center for Disease Control

U.S. Dept. of Health and Human Services

At lanta, GA 30333

\section{ONSITE}

DOE Richland Operations office

K. W. Bracken

37 Pacific Northwest Laboratory

W. J. Bair

C. D. Becker

J. B. Brown, Jr.

D. W. Dragnich

C. E. Elderkin

R. H. Gray

J. M. Hales

P. C. Hays

D. D. Mahlum

P. J. Mellinger (15)

T. L. Page

W. F. Sandusky

R. G. Schreckhise

D. R. Simpson

J. A. Stott lemyre

R. E. Wildung

Publishing Coordination (2)

Technical Information (5) 
